\title{
The Effectiveness of Kids Athletics Games as Motion Stimulation for Elementary School Children: A Literature Review
}

\author{
Dakwatul Anisah*, Amrozi Kamidi, Abdul Rachman Syam Tuasikal, Suroto \\ Universitas Negeri Surabaya \\ *dakwatulanisah@gmail.com
}

\begin{abstract}
The development of science and technology and various kind of facilities have caused children nowadays and including elementary school children to have new hobbies such as playing "play stations game", computers or internet usage. The new hobbies cause sedentary behavior in children. Sedentary behavior negatively impacts the health, growth and development of elementary school children. To overcome this problem, it can be given a game at school for elementary school children called kids athletics game. Kids' athletics game is a form of game method that is suitable for elementary school children as a stimulation of elementary school children's movements. The purpose of this review is to find out the effectiveness of kids athletics game as a stimulation of elementary school children. The method used is a journal search system on Google with the keyword kids' athletic games on children's movements. Journals are used as literature with full text inclusion criteria, the subjects are elementary school children, type of journals are journals of the last 6 years. The results of the review showed that kids' athletics games can improve motion in elementary school children. The conclusion in this journal review is an effective kids' athletics game as a stimulation of elementary school children's movements.
\end{abstract}

Keywords: Kids’ Athletics Games, Movement, Elementary School Children 


\section{STRADA Jurnal Ilmiah Kesehatan}

DOI: $10.30994 /$ sjik.v9i2.328

ISSN: 2252-3847 (print); 2614-350X (online)

Vol.9 No.2 November 2020 Page.488-493

\section{BACKGROUND}

The development of science and technology creating various kinds of facilities that leads to an increase in sedentary behavior (Ludyanti, 2019). Children nowadays including elementary school children have new hobbies such as playing "play stations game", computers or internet usage. This results in children who are moveless because they just sit quietly in front of the television or computer. In Indonesia, 57.3\% of Indonesian children are categorized as inactive and in front of a TV / computer / PS $\geq 2$ hours per day (Heryudarini et al., 2013). Based on the results of research on school-age children respondents showed that on weekends the average sedentary behavior increased to 4.98 hours / day from weekday days which had an average of 3.55 hours / day (Setyoadi et al., 2015). In the age group of primary school children who have an inactive lifestyle has a percentage of $67 \%$ (Burhaein, 2017). Problems related to sedentary behavior in these children need more attention.

Sedentary behavior has a negative effect on health which makes it an important issue in public health (Ochoa, et al., 2013). Sedentary behavior is a group of behaviors that occur when sitting or lying down which requires very low energy expenditure, such as sitting or lying while watching television, playing electronic games, reading, etc (Arundhana, Hadi, \& Julia, 2013). Impacts that can be caused by sedentary behavior include cardio metabolic disorders, respiratory disorders (asthma), psychosocial disorders (anxiety, depression, low self-esteem) and also include growth and development disorders (Cliff, 2016). Ludyanti (2019) also said that sedentary behavior that occurs in children can interfere with children's development. Moreover, many children who do not have a fit body due to a lack of motion sickness (Heryudarini et al., 2013).

The increased use of sedentary time on weekends is due to the opportunity to do more sedentary behavior compared to weekday. Sedentary behavior in children themselves is influenced by several factors such as economic status, parental education and the environment (Setyoadi et al., 2015). Primary school children are advanced age after passing through the golden age (early age), so that activities are needed in accordance with the age of growth and development (Burhaein, 2017). Baharudin \& Hartoto (2016) added that in childhood period where children are very active in carrying out activities, one of them is sports activities. Sports activities in children are affected by mobility. In addition, sports activities in children are very close to the game. The game is something that is considered mandatory as a means for physical development and movement for children (Hasanah, 2016).

Children tend to do a movement activitiy even though it still looks very simple like playing (Rubiyanto, 2014). The world of children is playing, while the game is an activity carried out by everyone including children. Children are tending to love this type of game which is challenging and involves many friends as a form of social interaction with their peers (Rumini, 2014). One of Games for children in sports is Kids Athletics. Kids Athletics is a basic sport motion activity that aims to introduce basic motion for children (IAAF Kids Athletics, 2002). Research conducted by Teneh et al. (2015) that the kids atheletics game is effectively applied in the learning of elementary school children's movements. In addition, research conducted by Rumini (2014) showed that learning kids athletics games can be used as a basic athletic movement development in children. Based on the background above, this journal review aims to find out the effectiveness of kids athletics as a stimulation of elementary school children's movements. 


\section{STRADA Jurnal Ilmiah Kesehatan}

DOI: $10.30994 /$ sjik.v9i2.328

ISSN: 2252-3847 (print); 2614-350X (online)

Vol.9 No.2 November 2020 Page.488-493

\section{METHODS}

The inclusion criteria used are: full text (journals that can be downloaded), humans (subjects in this study are elementary school children), type of journal is the journal for the last 6 years. The method used in the journal review this time is to use the Google search with the keyword kids' athletics game on children's movements, then journals that match the keywords were reviewed based on intervention models, methods, samples, and research results. In google obtained 5 literature.

Table 1. Characteristics of Research

\begin{tabular}{|c|c|c|c|c|c|}
\hline No & Author & $\begin{array}{c}\text { Intervention } \\
\text { Model }\end{array}$ & Method & Sample & Result \\
\hline 1. & $\begin{array}{l}\text { Dimyati, } \\
2017 .\end{array}$ & $\begin{array}{l}\text { Children's } \\
\text { athletic } \\
\text { games (kids } \\
\text { athletics } \\
\text { formula 1) in } \\
\text { learning } \\
\text { motion }\end{array}$ & $\begin{array}{l}\text { Development } \\
\text { research }\end{array}$ & $\begin{array}{l}20 \text { deaf } \\
\text { students }\end{array}$ & $\begin{array}{l}\text { Development of } \\
\text { children's athletic game } \\
\text { models can be applied } \\
\text { in motion learning }\end{array}$ \\
\hline 2. & $\begin{array}{l}\text { Teneh et } \\
\text { al., } 2015\end{array}$ & $\begin{array}{l}\text { Kids' } \\
\text { athletics } \\
\text { game on the } \\
\text { effectiveness } \\
\text { of motion } \\
\text { learning }\end{array}$ & $\begin{array}{l}\text { Experimental } \\
\text { research with } \\
\text { pre-test and } \\
\text { post-test design }\end{array}$ & $\begin{array}{l}26 \text { SDIT AL } \\
\text { FAHMI } \\
\text { students }\end{array}$ & $\begin{array}{l}\text { There is an increase in } \\
\text { kid's athletic play on } \\
\text { effectiveness motion } \\
\text { learning in SDIT Al } \\
\text { Fahmi Palu. }\end{array}$ \\
\hline 3. & $\begin{array}{l}\text { Rumini, } \\
2014\end{array}$ & $\begin{array}{l}\text { Kids athletics } \\
\text { as a form of } \\
\text { basic motion } \\
\text { development }\end{array}$ & $\begin{array}{l}\text { Conseptual } \\
\text { review }\end{array}$ & Children & $\begin{array}{l}\text { Kids' athletics game } \\
\text { learning can be used as } \\
\text { a basic athletic motion } \\
\text { development in } \\
\text { children }\end{array}$ \\
\hline 4. & $\begin{array}{l}\text { Hindriani, } \\
2018\end{array}$ & $\begin{array}{l}\text { Kids athletics } \\
\text { on primary } \\
\text { school } \\
\text { students }\end{array}$ & $\begin{array}{l}\text { Quantitative } \\
\text { Descriptive }\end{array}$ & $\begin{array}{l}129 \text { students } \\
\text { from SDN } \\
\text { 19, SDN 74, } \\
\text { SDN 02, dan } \\
\text { SDN 01 }\end{array}$ & $\begin{array}{l}\text { The ability of kids } \\
\text { athletics in all students } \\
\text { in the category is lack }\end{array}$ \\
\hline 5. & $\begin{array}{l}\text { Wicaksono, } \\
2018\end{array}$ & $\begin{array}{l}\text { Kids' } \\
\text { athletics } \\
\text { game }\end{array}$ & $\begin{array}{l}\text { Pseudo- } \\
\text { experiment } \\
\text { pretest-Posttest } \\
\text { control Group } \\
\text { Design with } \\
\text { quantitative } \\
\text { research }\end{array}$ & $\begin{array}{l}\text { Fifth grade } \\
\text { students of } \\
\text { Sekolah } \\
\text { Dasar Negeri } \\
2 \text { Tasikmadu, } \\
\text { Sub-district } \\
\text { Watulimo, } \\
\text { Trenggalek } \\
\end{array}$ & $\begin{array}{l}\text { With students learning } \\
\text { kids athletics, the } \\
\text { students' basic mobility } \\
\text { will improve, these } \\
\text { capabilities include } \\
\text { locomotor, non- } \\
\text { motomotor and }\end{array}$ \\
\hline
\end{tabular}




\section{STRADA Jurnal Ilmiah Kesehatan}

DOI: $10.30994 /$ sjik.v9i2.328

\begin{tabular}{|l|l|l|l|l|}
\hline & & approach & & $\begin{array}{l}\text { manipulative } \\
\text { abilities.capabilities } \\
\text { include locomotors, } \\
\text { non-locomotor and } \\
\text { manipulative abilities. } \\
\end{array}$ \\
& & & & \\
\hline
\end{tabular}

\section{RESULT}

The results of a review of 5 journals obtained 4 journals that children's athletic games (kids athletics formula 1) with a sample of 20 children can be applied in motion learning (Dimyati, 2017). Kids athletics games are effective in learning motion in 26 elementary students of IT Al Fahmi Palu (Teneh et al., 2015). Kids athletics in 129 students from four elementary schools, namely SDN 19, SDN 74, SDN 02 and SDN 01 are categorized as very poor (Hindriani, 2018). Kids athletics games can improve students' basic mobility abilities, which include locomotor, non-locomotor and manipulative abilities (Wicaksono, 2018). Based on the results above shows that the kids athletics game is effective as a stimulation of motion for elementary school children.

\section{DISCUSSION}

Kids' athletics game is a form of game that comes from the development of athletics carried out by adults, then developed as a model of children's games (Rumini, 2014). Kids' Athletics is a beneficial factor of the integration process of children. The concept of teamwork, where everyone contributes to the game, opens opportunities for children to meet and accept their differences. The simplicity of the rules and the safety of the matches provided, allows children to play as official and full team coaches. This responsibility they will take on certain events when they can experience it in society as a stimulus to the formation of children's character. Kids' Athletics has the benefit so that they can truly experience winning the match that they are participating in. The strategy chosen (team, match, and organization) in groups to make the match results unpredictable until the final match (IAAF Kids Athletics, 2002). Kids' athletics games provide excitement, new exercises and varied movements (Rumini, 2014). An innovative model will allow children to do basic activities such as: sprinting (endurance running), endurance running (endurance running), jumping, throwing (IAAF Kids Athletics, 2002). Kids' athletics games can be played by a relatively large number of children, so the playing area and game time must be taken into account. Through movements in the kids athletics game (running, jumping, throwing), the children can participate in an atmosphere of play, not tense, and in pleasant situations (Rumini, 2014). Besides kids' athletics are designed in the form of games, so that children are motivated to do sports with enthusiasm. Kids' Athletics are made to cause no boredom (Ningrum, 2019).

The Kids' Athletics game contains the basic components of running, jumping and throwing (Ningrum, 2019). In the running group includes sprint hurdles, slalom sprints, formula I sprints, endurance runs. In the group jump include jumping long using the pole, jumping rope, frog jumping, cross jumping. Whereas in the throw group are target throw, turbo throw, and rotation throw (Rumini, 2014). This shows that the movements in the 


\section{STRADA Jurnal Ilmiah Kesehatan}

DOI: $10.30994 /$ sjik.v9i2.328

ISSN: 2252-3847 (print); 2614-350X (online)

Vol.9 No.2 November 2020 Page.488-493

kids' athletic game are very complex and in accordance with the development and growth of elementary school children, so it is very effective as a stimulation of elementary school children's movements.

\section{CONCLUSION}

Based on the results and discussion of the review in the journal above, an intervention model that can be used for motion stimulation is a children's athletic game. The method that can be used for children's athletic games as motion stimulation uses development research methods, and can also use experimental research methods (the design of an experimental control group pretest-posttest-posttest with quantitative research research). The sample used for motion stimulation is elementary school children. The results in this review article made that athletic children's games are effective as a stimulation of elementary school children 's movements. This is because, the form of athletic games for children is in accordance with the development and growth of elementary school children. In addition, children's athletic games are games that can be done at school by students who are guided by a teacher.

\section{REFERENCES}

Arundhana, A. I., Hadi, H., \& Julia, M. (2013). Perilaku Sedentari Sebagai Faktor Risiko Kejadian Obesitas Pada Anak Sekolah Dasar Di Kota Yogyakarta Dan Kabupaten Bantul. Jurnal Gizi Dan Dietetik Indonesia, 1(2), 71-80.

Baharudin, L. \& Hartoto, S. 2016. Hubungan Antara Aktivitas Olahraga Dengan Kemampuan Gerak Dasar Siswa (Studi Pada Kelas IV, V dan VI SD NEgeri 7 Sidokumpul Gresik). Jurnal Pendidikan Olahraga dan Kesehatan, 04(01): 236 241.

Burhaein, Erick. 2017. Aktivitas Fisik Olahraga untuk Pertumbuhan dan Perkembangan Siswa SD. Indonesian Journal of Primary Education, 1(1): 51-58.

Cliff, et al. (2016). Objectively Measured Sedentary Behaviour and Health and Development in Children and Adolescents: systematic review and meta-analysis. Pediatric Obesity/Behaviour. World Obesity, 17, 330-344.

Dimyati, A. 2017. Pengembangan Model Permainan Atletik Anak Dalam Pembelajaran Gerak Dasar Lari Bagi Siswa Berkebutuhan Khusus (Tunarungu) Di SLB Negeri Kabupaten Karawang. Journal Sport Area, 19-26.

Hardini, K.F., Sari, G.M, Effendi, C. 2020. Pump It Up and Zig Zag Run Training Improve

Children Agility Age 7-8 Years Old. STRADA Jurnal Ilmiah Kesehatan,

9(1): 54-59.https://doi.org/10.30994/sjik.v9il.268.

Hasanah, U. 2016. Pengembangan Kemampuan Fisik Motorik Melalui Permainan Tradisional Bagi Anak Usia Dini. Jurnal Pendidikan Anak, 5(1): 717-733.

Heryudarini, $\mathrm{H}$ et al.. 2013. Pola Aktivitas Fisik Anak Usia 6-12,9 tahun. Gizi Indonesia, 36 (2):99-108.

Hindriani, D. 2018. Analisis Kemampuan Kids Athletics Pada Siswa Sekolah Dasar di Kota Bengkulu. Jurnal Ilmiah Pendidikan Jasmani, 1(3): 23-31. IAAF. 2002. Kids Athletics. Jerman: IAAF.

Ludyanti, L.N. 2019. Perilaku Kurang Gerak (Sedentary Behaviour) Dengan PerkembanganPsikososial Anak Pra Sekolah. Jurnal Ilmiah Ilmu Kesehatan, 7(2): 22-31. 


\section{STRADA Jurnal Ilmiah Kesehatan}

DOI: $10.30994 /$ sjik.v9i2.328

ISSN: 2252-3847 (print); 2614-350X (online)

Vol.9 No.2 November 2020 Page.488-493

Ningrum, E. C. 2019. Perbedaan Pengaruh Latihan Konvensional dan Kids Athletics Terhadap Kemampuan Motorik Kasar Atlet Atletik Kota Kediri Usia 11-12 Tahun. Skripsi : Universitas Negeri Yogyakarta.

Ochoa, M., Moreno, A., Martinez, A., and Marti, A. 2013. Predictor Factors for Childhood Obesity in a Spanish Case Control Study. Nutrition Journal, 23, 379-384. Retrieved from http://www.ncbi.nlm.nih.gov/pubmed/17408922.

Setyoadi; Rini, Ika Setyo; Novitasari, T. 2015. Hubungan Penggunaan Waktu Perilaku Kurang Gerak (Sedentary Behaviour) Dengan Obesitas Pada Anak Usia 9-11 Tahun Di SD Negeri Beji 02 Kabupaten Tulungagung. Jurnal Ilmu Keperawatan, 3(2).

Rubiyanto. 2014. Peranan Aktivitas Olahraga Bagi Tumbuh Kembang Anak. Jurnal Pendidikan Olahraga, 3(1): 54-64.

Rumini. 2014. Pembelajaran Permainan Kids Athletics Sebagai Wujud Pengembangan Gerak Dasar Atletik Pada Anak-Anak. Journal of Physical Education, Health and Sport, 1(2): 98-107.

Teneh, F., Mentara, H., Hariyadi, T. 2015. Pengaruh Permainan Kids Athletics TerhadapEfektivitas Pembelajaran Gerak Pada Siswa SD IT Al Fahmi Palu. EJournal Tadulako Physical, Health and Recreation, 3(12): 2337-4535.

Wicaksono, B. K. P. 2018. Pengaruh Permainan Kids Athletics Terhadap Tingkat Kebugaran Siswa Kelas V Sekolah Dasar Negeri Tasikmadu Kecamatan Watulimo Kabupaten Trenggalek. Simki-Techsain, 2(5): 1-5. 